\title{
AC 2010-1285: PRACTICAL, EFFICIENT STRATEGIES FOR ASSESSMENT OF ENGINEERING PROJECTS AND ENGINEERING PROGRAMS
}

\section{Kevin Dahm, Rowan University}

Kevin Dahm is an Associate Professor of Chemical Engineering at Rowan University. He received his B.S. from Worcester Polytechnic Institute in 1992 and his Ph.D. from Massachusetts Institute of Technology in 1998. He has published in the areas of engineering design, pedagogically sound uses for simulation and computing, assessment of student learning, and teaching engineering economy. He has received four ASEE awards: the 2002 PIC-III award, the 2003 Joseph J. Martin Award, the 2004 Raymond W. Fahien Award and the 2005 Corcoran Award. 


\title{
PRACTICAL, EFFICIENT STRATEGIES FOR ASSESSMENT OF ENGINEERING PROJECTS AND ENGINEERING PROGRAMS
}

\begin{abstract}
The process of seeking and gaining accreditation for an engineering program was substantially changed ten years ago when the EC2000 criteria were implemented. (The moniker EC2000 is no longer in use; they are now simply the ABET criteria.) Programs must now define goals and objectives for their program, provide evidence that graduates are meeting these objectives, and demonstrate evidence of continuous improvement. These accreditation criteria present programs with significant challenges. Departments must determine what data are needed and collect it regularly. To be sustainable, assessment plans must make efficient use of faculty time. This paper will present strategies for collecting assessment data that serves multiple purposes beyond accreditation, using the Rowan University Junior/Senior Engineering Clinic as an example.
\end{abstract}

The Rowan University Junior/Senior Engineering Clinic is a multidisciplinary, projectbased course required for engineering students in all disciplines. Students solve real engineering research and design problems, many of which are sponsored by local industry. Because each clinic project is unique, grading student work and maintaining approximately uniform expectations across all projects is a significant challenge. At the same time, the Clinic is the course within the Rowan Engineering curriculum that best reflects professional engineering practice. Consequently, the Junior/Senior Clinic provides an excellent forum for assessing whether students have indeed achieved the desired pedagogical outcomes of the curriculum. This paper will present a set of assessment rubrics that is currently being used by the Rowan Chemical Engineering department. The data collected serves two purposes: It is used to grade individual student projects and it is used for program-level assessment.

The assessment strategies presented are of potential utility to any engineering faculty member, but may be of particular interest to new faculty members, for whom research productivity and generation of publications are essential. This paper will present evidence that the implementation of the assessment process led directly to improved student performance in the $\mathrm{Jr} / \mathrm{Sr}$ Clinic, and thus improved the overall research productivity of the entire department. Further, new faculty members often have innovative ideas for classroom teaching. This paper will demonstrate how the assessment rubrics have been used as a tool for turning pedagogical innovations into publishable pedagogical scholarship.

\section{Programmatic Assessment for Engineering Background}

Since 2000, ABET $^{1}$ has required that in order to be accredited, engineering programs must demonstrate evidence of continuous assessment and continuous improvement. Components of a good assessment strategy include: 
1) Establish goals and desired educational outcomes for the degree program, which must include 11 outcomes ${ }^{2}$ (designated "A-K") identified by ABET as essential for all engineering programs

2) Measure whether graduates of the program are attaining the goals and outcomes

3) Use the data collected in step 2 to identify opportunities for improvement, and modify the program accordingly

4) "Close the loop" by assessing whether the changes led to improved attainment of desired outcomes ${ }^{1}$

According to Gloria Rogers ${ }^{3}$ the most difficult part of the process, and one which most engineering programs do not do well, is "identification of a limited number of performance indicators for each outcome." An outcome is a broad statement such as "The Chemical Engineering Program at Rowan University will produce graduates who demonstrate an ability to apply knowledge of mathematics, science, and engineering," which mirrors ABET outcome $A^{1}$. Dr. Rogers notes that programs "...tend to go from broad outcomes to data collection without articulating specifically what students need to demonstrate..." 3 The next section discusses a strategy which was employed at Rowan University for our first two ABET visits in 2000 and 2006.

\section{Strategies Employed at Rowan University}

The Rowan University Chemical Engineering department developed a set of assessment rubrics which were published previously in Chemical Engineering Education ${ }^{4}$. A sample rubric is shown in Table 1. For each outcome, 3-6 indicators were identified, and these are located in the leftmost column. For each indicator, precise descriptions of four different levels of achievement were devised. When reviewing a sample of work product (exam, lab report, etc.) the evaluator simply moves from left to right until he/she finds the descriptor that is accurate for the student's work. The department also did a study ${ }^{4}$ which demonstrated that these rubrics provide excellent consistency for different raters evaluating a particular exam or report. This result highlights one significant merit of the indicators. Inter-rater reliability would presumably not be present if the evaluator was making a single, holistic determination of whether the student "demonstrates an ability to apply knowledge of mathematics, science and engineering," or if the evaluator were rating work on a scale from 1-4 with no specific description of what each number meant.

While these rubrics were an effective tool for measuring student achievement of goals and objectives, it would have been impractical to apply them to every student assignment. Further, not all outcomes can be assessed from all assignments; an exam, for example, isn't particularly useful in assessing the outcome "The Chemical Engineering program will produce graduates who have effective written communication skills." The department consequently chose a portfolio of five assignments (Unit Operations Lab report, Chemical Plant Design final report, HAZOP report, Chemical Reaction Engineering final exam and Junior/Senior Clinic final report) and determined that every program outcome was substantially addressed by at least two of these. 
The rubrics were applied to the portfolios each year from 2000-2006, and data was compared across years. Several programmatic improvements have resulted from this process; one example will be given here. The spring 2005 portfolios consisted of writing assignments that were good overall, but a number had weak literature reviews. The department took a number of steps to improve the problem, as summarized in Appendix 1. Notably, however, the weakness likely would not have been identified at all without the formulation of specific indicators within each objective. Because the writing assignments were generally good, grades or other holistic measures of quality of the assignment would not have detected a problem. This is one of several reasons ${ }^{5}$ why ABET recommends not using student grades as assessment instruments.

\section{Multiple Uses for Assessment Data}

The previous section provided a nutshell description of an effective assessment plan and its use in evaluating and improving an engineering program. The primary drawback of this strategy is that the process of evaluating portfolios is very time-consuming. Using time efficiently is a priority for any faculty member. This section demonstrates how assessment data can be collected and used for multiple purposes. It uses the Rowan University Junior/Senior Engineering Clinic as an example.

\section{Junior/Senior Engineering Clinic}

Rowan University has an eight-semester Engineering Clinic program that provides Engineering students with experience solving practical, open-ended engineering problems. The sequence culminates in the Rowan Junior/Senior Engineering Clinic, in which students work on real engineering research and design projects. Project teams work with close faculty supervision and usually consist of 3-4 students; sometimes drawn from a single discipline and sometimes representing several, depending on the needs of the particular project. Most projects are externally sponsored, either by local industry or government agencies.

The Mechanical Engineering and Electrical and Computer Engineering programs use Junior/Senior Clinic as the capstone design experiences in their programs. While the Chemical Engineering and Civil and Environmental Engineering departments have separate capstone design courses, these departments also recognize Junior/Senior Clinic as a course that well reflects engineering practice. Consequently Junior/Senior Clinic figures prominently in the assessment efforts of all four programs. As noted in the previous section, the Junior/Senior Clinic final reports were included in the portfolios of student work that were reviewed at the end of every year. While the department obtained valuable data from the portfolio evaluation, an inefficiency in the process was also evident: each paper was being read by the project supervisor(s), who assigned a grade to the report, and then was read a second time, by different faculty member(s), who evaluated it using the rubrics for assessment purposes. The next section describes a new system that has been implemented to accomplish both tasks in a single reading.

Rubrics for Assessing Engineering Clinic Projects 
Two members of the department produced a second set of rubrics, designed specifically for Junior/Senior Engineering Clinic projects. (It is expected the rubrics could be applied, with little or no modification, to undergraduate engineering research projects at other universities.) Sixteen elements of a Clinic project were identified, and for each, descriptions of four levels of performance were written. These rubrics were published in Chemical Engineering Education ${ }^{6}$, and two of the original 16 rubrics are shown in Table

2. Levels of performance were mapped to letter grades $(\mathrm{A}, \mathrm{B}, \mathrm{C}$ and $\mathrm{D} / \mathrm{F})$ and the rubrics were passed out to students on the first day of Junior/Senior Clinic in order to clarify expectations for the course. Note that the rubrics are intended for overall evaluation of a team project; separate mechanisms are needed for evaluating individual contributions to the project. Most Rowan engineering faculty use the peer evaluation form designed by Felder. ${ }^{7}$

The project supervisor evaluates a deliverable (mid-semester report, final report, final presentation etc.) by going through the 16 elements and determining the level of the team's performance, with respect to that element. This data can then be used for assigning grades, for programmatic assessment, and for other purposes as well.

\section{Assigning Project Grades}

Individual faculty have the freedom and flexibility to determine the weighting of the 16 project elements in grading individual projects, but teams that perform at B-level for most or all of the 16 elements would expect to receive a B for the course. Some faculty members ask their student teams to provide a written self-evaluation of their performance with respect to each of the 16 elements, including specific evidence for each rating.

The department piloted the rubrics in 2003, and conducted a study of their effect. In 2002, the rubrics were not communicated to the students and were not used in grading projects, and the average grade assigned for all students was $\mathrm{B}+$. However, after assigning and submitting grades, each faculty member evaluated his/her teams using the rubrics. The ratings were converted to numbers $(A=4, B=3$ etc. $)$ and the average rating assigned across all teams, with all elements weighted equally, was 2.8. In other words, while the average grade was $\mathrm{B}+$, the average performance as measured by the rubrics was somewhere between a B and a B-.

In spring 2003, when the rubrics were used for the first time, the average grade assigned was again $\mathrm{B}+$, but this time, the average performance as measured by the rubrics was also $\mathrm{B}+$ (3.3). Note that the department only runs $10-12$ projects per semester and at that sample size, the improvement was not statistically significant. However, the results suggest that the act of communicating clear expectations to the students, in the form of grading rubrics, led to more successful, more productive projects.

Table 3 shows the results of a survey ${ }^{8}$ of the faculty members who used the rubrics and the response was positive. The consensus was that use of the rubrics made grading more fair, because the expectations were clear and were uniform (to the degree that that is possible given that every project is unique). The rubrics have been used for assigning 
grades in Junior/Senior Clinic ever since. The department reviews them annually and makes revisions to improve clarity or add more detail and specificity. For example, it was noted that the original rubrics evaluated content effectively but were less clear on expectations regarding the quality of communication (writing and presentation). There are now a total of 27 rubrics, nine of which are explicitly dedicated to formal communication.

In 2006, the department also began using the grading rubrics for program-level assessment, as described in the next section.

\section{Program Assessment}

There is substantial overlap in the information collected by both sets of rubrics described here (Tables 1 and 2). The difference is primarily one of organization. Table 1 is organized according to the program's goals and educational outcomes. Table 2 is organized to mirror a team's progression through a project, starting with the establishment of objectives and concluding with recommendations for future work. However, each of these aspects of a project falls within the scope of one or more of the department's educational outcomes; an example of the "mapping" of grading rubrics to program outcomes is shown in Table 4. Consequently, the 27 grading rubrics serve exactly the same role as the indicators shown in Table 1.

Since the department was due for an ABET visit in 2006, the department chose to maintain the portfolio system described under "Strategies Employed at Rowan University" for the entire 2000-2006 cycle and transition to a new system at the start of the next cycle. Grading rubrics comparable to those shown in Table 2 were written for Chemical Plant Design (the capstone design course) and a mapping comparable to Table 4 was created for this course as well. By using these mappings, the department now obtains substantially the same assessment information it obtained from the portfolios, while using faculty time more efficiently.

\section{Publication of Pedagogical Scholarship}

Active faculty who are concerned with delivering quality education are routinely trying out new ideas. It is beneficial for a faculty member to disseminate his/her pedagogical innovations in the form of educational publications, particularly for newer faculty who are concerned with making tenure, promotion etc. Assessment tools like those described in this paper can be used to elevate a body of work from "an interesting idea that seems to work pretty well" to a publishable piece of pedagogical scholarship.

Wankat ${ }^{9}$ recently commented on the evolution of standards for engineering education publications, saying "Early engineering education research papers were seldom rigorous and often did not contain any data or references." In 1993, Journal of Engineering Education established standards for publication that included the need for appropriate referencing of relevant literature and assessment in some form. ${ }^{10}$ The journal has since further increased its standards ${ }^{11,12}$ to require rigorous educational research, which Wankat 
summarizes as "engineering education research have hypotheses on significant questions stated in advance and then tested during the research, have a thorough literature review, ground the research with a theory of learning or human development, include an appropriate mix of quantitative and qualitative research tools, and obtain approval or an exemption in advance from the Institutional Review Board (IRB) if students are involved.",

The assessment practices described in this paper do not meet the "rigorous research" standard. However, Wankat indicates ${ }^{9}$ that Chemical Engineering Education uses roughly the 1993 JEE paradigm as a standard for publication, and notes that "This quality level was accessible to all engineering professors since it could be met by doing classroom research that included student course evaluations and/or surveys plus cited appropriate references."9 Other engineering disciplines also have educational journals with comparable standards for publication. For papers of interest to a broader audience, ASEE's new (established in 2007) journal Advances in Engineering Education was created as an outlet for "innovative curricula, courses, and teaching practices both within and outside the classroom that are clearly built upon a foundation of accepted learning science principles ${ }^{13}$;" a category of papers that JEE published prior to shifting its emphasis to rigorous research exclusively. Advances in Engineering Education thus requires authors to demonstrate a legitimate innovation that effects an improvement in engineering education, but does not use the "rigorous research" standard.

Three examples ${ }^{14,15,16}$ of refereed journal articles that used assessment data collected with the instruments described in this paper are described briefly:

1) Two faculty members conducted a control experiment on improving the performance of student teams. Junior/Senior Clinic teams were divided into four sub-groups: one group did targeted writing exercises designed to encourage self-reflection during the project, one group went through a workshop on learning patterns and learned how their patterns compared with those of their teammates, one group did both of these activities and the control group did neither. Surveys showed ${ }^{14}$ that the four groups had different attitudes towards team projects at the end of the semester. However, it was also valuable to have an objective measure of whether the quality of the work produced by the four cohorts was different. Because the entire department was using the same grading rubrics, this objective measure was available with no additional effort on the part of the authors or any other faculty member. The results showed that the teams that went through the workshop on learning patterns, regardless of whether or not they also did the targeted writing exercises, produced better final project reports than did the control group.

This is one of several of refereed journal publications that used assessment data collected with the instruments described in this paper. To describe the others briefly:

2) Sophomore Engineering Clinic I is an integrated course in which technical writing and engineering design are taught concurrently. Prior to 2004 the course always employed a semester-long design project. In 2004 the Sophomore Clinic team replaced the semester- 
long project model with a sequence of design projects of continuously increasing complexity. It was hypothesized that if this change was beneficial, students should perform better in subsequent courses (Sophomore Engineering Clinic II and capstone design courses) that involved substantial design content. Design reports from these courses were evaluated using the rubrics shown in Table 1. It was shown ${ }^{14},{ }^{17}$ that students who took Sophomore Clinic I in 2004 produced better design reports in subsequent courses than students who took Sophomore Engineering Clinic in 2003.

3) A second year faculty member, teaching a biochemical engineering course for the second time, introduced a new experimental project called the "protein production challenge." In order to determine whether this activity led to improved student performance, the rubrics in Table 1 were applied to final exams from the course, using the first offering of the course (which didn't include the protein production challenge) as a control group. The evaluator was a different faculty member who didn't know which students were in the experimental group and which were in the control group until after the evaluation was complete. The results showed superior performance for the students who completed the protein production challenge. ${ }^{16}$

\section{Summary and Conclusion}

This paper provides a brief introduction to strategies for assessment, at the program level, the project level, and the course level. It also provides examples (Table 1, Table 2) of effective instruments for assessment, and demonstrates that carefully designed assessment instruments can be used to fulfill multiple roles. While ABET does not regard student grades as useful assessment instruments ${ }^{5}$, it is quite efficient and feasible to collect raw assessment data, and then use that one set of data to inform both individual student (or team) grades and course- or program-level assessment. This paper also provides some indication that the very act of using a clear and detailed assessment instrument led to improved student performance on research projects, though no statistically significant conclusions can be drawn. Finally, it was shown that the same assessment data used for program assessment is also useful in assessing specific pedagogical innovations, meeting the standards for publication in some respected educational journals.

\footnotetext{
Bibliographical Information

${ }^{1}$ L.R. Latucca, P.E. Terenzini and J. F. Volkwein, "Engineering Change: A Study of the Impact of EC2000," ABET, Inc., Baltimore, MD 2006.

${ }^{2}$ ABET, Inc., "Criteria for Accrediting Engineering Programs," available at http://www.abet.org/Linked\%20Documents-UPDATE/Criteria\%20and\%20PP/E001\%2010$11 \% 20$ EAC\%20Criteria\%2011-03-09.pdf

${ }^{3}$ G. Rogers, "How are we Doing? Assessment Tips with Gloria Rogers," available at http://www.abet.org/Linked\%20Documents-UPDATE/Assessment/Assessment\%20Tips8.pdf
} 
${ }^{4}$ J. A. Newell, H. Newell, and K. D. Dahm, "Rubric Development and Inter-Rater Reliability Issues in Assessing Learning Outcomes," Chemical Engineering Education, 36, 3 (2002).

${ }^{5}$ G. Rogers, "Do Grades Make the Grade for Assessment?" available at http://www.abet.org/Linked\%20Documents-UPDATE/Assessment/Assessment\%20Tips4.pdf

${ }^{6}$ J. A. Newell, H. L. Newell, K. D. Dahm, "Rubric Development for Assessment of Undergraduate Research: Evaluating Multidisciplinary Team Projects," Chemical Engineering Education, 37, 3 (2003).

${ }^{7}$ Kaufman, D. B., R. M. Felder and H. Fuller, "Accounting for Individual Effort in Cooperative Learning Teams," Journal of Engineering Education, 89, 2, (2000).

${ }^{8}$ K. D. Dahm, J. A. Newell, H. L. Newell, "Rubric Development for Assessment of Multi-disciplinary Team Projects," ASEE Annual Conference and Exposition, June 2003, Nashville, TN.

${ }^{9}$ P. Wankat, "The Role of Chemical Engineering in Engineering Education Research," Proceedings of the ASEE Annual Conference and Exposition, June 2009, Austin, TX, available at http://soa.asee.org/paper/conference/paper-view.cfm?id=10806

${ }^{10}$ Ernst, E. W., "The Editor's Page," Journal of Engineering Education, 82 (1), 1 (1993).

${ }^{11}$ Lohmann, J. R., “The Editor's Page," Journal of Engineering Education, 92 (1), 1 (2003).

${ }^{12}$ Lohmann, J. R., “Editor's Page: Refining our Focus,” Journal of Engineering Education, 97 (1), 1 (2008).

${ }_{13}^{13}$ Advances in Engineering Education mission statement, available at http://advances.asee.org/mission.cfm

14 K. D. Dahm, J. A. Newell, R. Harvey and H. L. Newell, "The Impact of Structured Writing and Developing Awareness of Learning Preferences on the Performance and Attitudes of Engineering Teams," Advances in Engineering Education, 1, 4 (2009).

${ }^{15}$ K. Dahm, W. Riddell, E. Constans, R. Harvey, J. Courtney, and P. von Lockette "Implementing and Assessing the Converging-Diverging Model of Design in a Sequence of Sophomore Projects," Advances in Engineering Education, 1, 3 (2009).

${ }^{16}$ B. Lefebvre and K. Dahm, "Competition between student groups in the protein production challenge", Education for Chemical Engineers, 4, 1 (2009).

${ }^{17}$ K. Dahm and W. Riddell, "The Effect of Improvements in Sophomore Design Instruction on Performance in Subsequent Course Offerings," Proceedings of the ASEE Annual Conference and Exposition, June 2009, Austin, TX. 
Table 1: Sample rubric for the outcome "The Chemical Engineering Program at Rowan University will produce graduates who demonstrate an ability to apply knowledge of mathematics, science, and engineering (ABET - A)"

\begin{tabular}{|c|c|c|c|c|}
\hline Indicator & 4 & 3 & 2 & 1 \\
\hline $\begin{array}{l}\text { Formulates } \\
\text { appropriate } \\
\text { solution strategies }\end{array}$ & $\begin{array}{c}\text { Can easily convert } \\
\text { word problems to } \\
\text { equations. Sees what } \\
\text { must be done }\end{array}$ & $\begin{array}{l}\text { Forms workable } \\
\text { strategies, but may } \\
\text { not be optimal. } \\
\text { Occasional reliance } \\
\text { on brute force }\end{array}$ & $\begin{array}{l}\text { Has difficulty in } \\
\text { planning an } \\
\text { approach. Tends to } \\
\text { leave some } \\
\text { problems unsolved }\end{array}$ & $\begin{array}{c}\text { Has difficulty } \\
\text { getting beyond } \\
\text { the given unless } \\
\text { directly } \\
\text { instructed } \\
\end{array}$ \\
\hline $\begin{array}{l}\text { Identifies relevant } \\
\text { principles, } \\
\text { equations, and } \\
\text { data }\end{array}$ & $\begin{array}{l}\text { Consistently uses } \\
\text { relevant items with } \\
\text { little or no extraneous } \\
\text { efforts }\end{array}$ & $\begin{array}{l}\text { Ultimately identifies } \\
\text { relevant items but } \\
\text { may start with } \\
\text { extraneous info }\end{array}$ & $\begin{array}{c}\text { Identifies some } \\
\text { principles but } \\
\text { seems to have } \\
\text { difficulty in } \\
\text { distinguishing what } \\
\text { is needed. }\end{array}$ & $\begin{array}{c}\text { Cannot identify } \\
\text { and assemble } \\
\text { relevant } \\
\text { information }\end{array}$ \\
\hline $\begin{array}{l}\text { Systematically } \\
\text { executes the } \\
\text { solution strategy }\end{array}$ & $\begin{array}{c}\text { Consistently } \\
\text { implements strategy. } \\
\text { Gets correct answers }\end{array}$ & $\begin{array}{l}\text { Implements well. } \\
\text { Occasional minor } \\
\text { errors may occur }\end{array}$ & $\begin{array}{l}\text { Has some difficulty } \\
\text { in solving the } \\
\text { problem when data } \\
\text { are assembled. } \\
\text { Frequent errors. }\end{array}$ & $\begin{array}{c}\text { Often is unable } \\
\text { to solve a } \\
\text { problem, even } \\
\text { when all data are } \\
\text { given }\end{array}$ \\
\hline $\begin{array}{l}\text { Applies } \\
\text { engineering } \\
\text { judgment to } \\
\text { evaluate answers }\end{array}$ & $\begin{array}{l}\text { Has no unrecognized } \\
\text { implausible answers }\end{array}$ & $\begin{array}{l}\text { Has no more than one } \\
\text { if any unrecognized } \\
\text { implausible answers. } \\
\text { If any it is minor and } \\
\text { obscure }\end{array}$ & $\begin{array}{c}\text { Attempts to } \\
\text { evaluate answers } \\
\text { but has difficulty. } \\
\text { Recognizes that } \\
\text { numbers have } \\
\text { meaning but cannot } \\
\text { fully relate. }\end{array}$ & $\begin{array}{l}\text { Makes little if } \\
\text { any effort to } \\
\text { interpret results. } \\
\text { Numbers appear } \\
\text { to have little } \\
\text { meaning }\end{array}$ \\
\hline
\end{tabular}


Table 2: Example rubrics for evaluation of Junior/Senior Engineering Clinic projects.

\begin{tabular}{|l|l|l|}
\hline Grade & $\begin{array}{l}\text { Definition of Project } \\
\text { Objectives }\end{array}$ & $\begin{array}{l}\text { Recommendations for } \\
\text { Future Work }\end{array}$ \\
\hline An "A" team & $\begin{array}{l}\text { Actively involved in } \\
\text { defining aggressive and } \\
\text { achievable objectives that } \\
\text { thoroughly address } \\
\text { fundamental project needs }\end{array}$ & $\begin{array}{l}\text { Makes insightful } \\
\text { recommendations for future } \\
\text { work }\end{array}$ \\
\hline A "B" team & $\begin{array}{l}\text { Aids in defining objectives. } \\
\text { Some may be too simplistic } \\
\text { or unrealistic. }\end{array}$ & $\begin{array}{l}\text { Makes reasonable, but } \\
\text { broad/obvious, } \\
\text { recommendations for future } \\
\text { work }\end{array}$ \\
\hline A "C" team & $\begin{array}{l}\text { Takes little initiative in } \\
\text { defining the project, waits } \\
\text { to be told what to do }\end{array}$ & $\begin{array}{l}\text { Makes implausible } \\
\text { recommendations, or } \\
\text { overlooks obvious avenues } \\
\text { for future work }\end{array}$ \\
\hline A "D" or "F" team & $\begin{array}{l}\text { Doesn't even do what } \\
\text { they're told }\end{array}$ & $\begin{array}{l}\text { Makes no real } \\
\text { recommendations }\end{array}$ \\
\hline
\end{tabular}

Table 3: Faculty evaluation of the Junior/Senior Clinic grading rubrics.

\begin{tabular}{|l|c|}
\hline \multicolumn{1}{|c|}{ Statement } & $\begin{array}{c}\text { Mean Response }(4=\text { strongly agree; } \\
1=\text { strongly disagree })\end{array}$ \\
\hline $\begin{array}{l}\text { The grading rubrics helped me explain the } \\
\text { expectations of my project }\end{array}$ & 3.80 \\
\hline $\begin{array}{l}\text { The grading rubrics helped me determine } \\
\text { how my team would be graded }\end{array}$ & 3.70 \\
\hline $\begin{array}{l}\text { The grading rubrics helped me consider } \\
\text { project issues that I otherwise might not } \\
\text { have }\end{array}$ & 3.30 \\
\hline $\begin{array}{l}\text { I referred to the grading rubrics during the } \\
\text { semester }\end{array}$ & 3.40 \\
\hline $\begin{array}{l}\text { I think that clinic is more fair using grading } \\
\text { rubrics }\end{array}$ & 3.70 \\
\hline $\begin{array}{l}\text { I would like to use the rubrics again next } \\
\text { semester }\end{array}$ & 3.80 \\
\hline
\end{tabular}


Table 4: Mapping of aspects of Junior/Senior Clinic projects to five programmatic outcomes (the Chemical Engineering Program at Rowan has 18 total outcomes).

\begin{tabular}{|l|l|l|l|l|l|}
\hline & $\begin{array}{l}\text { Ability to } \\
\text { apply } \\
\text { knowledge of } \\
\text { mathematics, } \\
\text { science, and } \\
\text { engineering. }\end{array}$ & $\begin{array}{l}\text { Acquisition and } \\
\text { enterpretation of } \\
\text { results }\end{array}$ & $\begin{array}{l}\text { Design and } \\
\text { conduct } \\
\text { appropriate } \\
\text { experiments }\end{array}$ & $\begin{array}{l}\text { Working } \\
\text { knowledge } \\
\text { of chemistry } \\
\text { principles }\end{array}$ & $\begin{array}{l}\text { Working } \\
\text { knowledge } \\
\text { of chemical } \\
\text { engineering } \\
\text { principles }\end{array}$ \\
\hline Deadlines & & & & & \\
\hline Project Goals & & & & & \\
\hline Teaming & & & $\mathbf{X}$ & & \\
\hline $\begin{array}{l}\text { Project } \\
\text { Organization }\end{array}$ & & & & & \\
\hline Record Keeping & & $\mathbf{X}$ & & \\
\hline $\begin{array}{l}\text { Professional } \\
\text { Conduct }\end{array}$ & & & & & \\
\hline Professional Attire & & & & & \\
\hline Safety & & $\mathbf{X}$ & & $\mathbf{X}$ \\
\hline $\begin{array}{l}\text { Execution of } \\
\text { Project Plan }\end{array}$ & & & & & \\
\hline $\begin{array}{l}\text { Technical } \\
\text { Awareness }\end{array}$ & $\mathbf{X}$ & & & & \\
\hline $\begin{array}{l}\text { Underlying } \\
\text { Principles }\end{array}$ & & & & & \\
\hline $\begin{array}{l}\text { System or } \\
\text { Apparatus Design }\end{array}$ & $\mathbf{X}$ & & & & \\
\hline $\begin{array}{l}\text { Laboratory } \\
\text { Functions }\end{array}$ & & & & & \\
\hline $\begin{array}{l}\text { Modern } \\
\text { Engineering Tools }\end{array}$ & & & & & \\
\hline $\begin{array}{l}\text { Interpretation of } \\
\text { Results }\end{array}$ & $\mathbf{X}$ & $\mathbf{X}$ & & & \\
\hline $\begin{array}{l}\text { Societal/Global } \\
\text { Perspectives }\end{array}$ & & & & & \\
\hline Conclusions & & & & & \\
\hline Recommendations & & & & & \\
\hline $\begin{array}{l}\text { Writing: } \\
\text { Organization }\end{array}$ & & & & & \\
\hline $\begin{array}{l}\text { Writing: Level of } \\
\text { Detail }\end{array}$ & & & & & \\
\hline Writing: Abstract & & & & & \\
\hline Writing: Graphics & & & & & \\
\hline $\begin{array}{l}\text { Presentation: } \\
\text { Introduction }\end{array}$ & & & & & \\
\hline $\begin{array}{l}\text { Presentation: } \\
\text { Organization }\end{array}$ & & & & & \\
\hline $\begin{array}{l}\text { Presentation: Level } \\
\text { of Detail }\end{array}$ & & & & & \\
\hline $\begin{array}{l}\text { Presentation: } \\
\text { Visual Aids }\end{array}$ & & & & \\
\hline $\begin{array}{l}\text { Presentation: } \\
\text { Discussion }\end{array}$ & & & & & \\
\hline
\end{tabular}




\section{Appendix 1: Improvement of Student Library Skills}

This is the exact text from the Rowan Chemical Engineering department's 2006 ABET self-study, describing how the department identified and addressed an apparent shortcoming in students' ability to write effective literature reviews:

Goal 2, objective 4 is as follows:

The Chemical Engineering Program at Rowan University will produce graduates who understand contemporary issues relevant to the field of chemical engineering (ABET - J). Graduates will have an awareness of current technical material (journals, trade publications, web sites, etc.), develop an ability to find relevant current information and use this ability in their curricular assignments.

The evaluation of student portfolios for the spring 2005 cohort showed a sharp decline in performance with respect to the three indicators for this objective. While portfolio reviews and other assessment instruments (peer evals, employer surveys etc.) have consistently indicated good written communication skills overall, the low scores on indicators 1 and 2 reflect a specific concern with student's abilities to write good literature reviews. Drastic steps were not warranted based on low scores for this one class, but the department took the following actions:

Incorporated a seminar on literature reviews and library research resources, conducted by a librarian, into the second week of the fall 2005 Junior/Senior Clinic.

$>$ Shared the concern with the College Assessment committee

$>$ Discussed the concern with the Freshman and Sophomore Clinic coordinators:

- The sophomore clinic team, in the fall of 2004, had already implemented some changes intended to generate more student interest and effort in the literature review assignment.

- The fall freshman clinic format was completely changed in the fall of 2005, and among the effects of the changes was a stronger emphasis on the Rowan Seminar goals of the course, one of which is library skills. The changes are described in detail in the summary of the fall 2005 marathon in Appendix I-D.

Note that the 2005 portfolio scores for Goal 3, objectives 1 and 2, which involve ethical responsibility and lifelong learning, were also lower than in previous years. Though the changes to freshman and sophomore clinic were precipitated by concerns about library skills, they should also help with these concerns. The new sophomore clinic assignment is a research paper on an engineering disaster, and the new freshman clinic format again involves a deeper commitment to "Rowan Seminar" goals, which include professionalism and good study habits as well as library skills.

Table 6. Mean portfolio scores with respect to Goal 2, Objective 4

\begin{tabular}{|r|r|r|}
\hline Indicator & Spring 2004 & \multicolumn{1}{c|}{ Spring 2005 } \\
\hline 1 & 3.125 & 2.555556 \\
\hline 2 & 2.875 & 2.111111 \\
\hline 3 & 3.5 & 3 \\
\hline
\end{tabular}

